\title{
Kompensacyjny charakter instytucji z art. 46 § 1 k.k. a obowiązek sądu zasądzenia odsetek od dnia wyrządzenia szkody
}

Wyrok Sądu Apelacyjnego w Warszawie z dnia 5 września 2018 r., II AKa 211/18

$Z$ faktu, że obecnie instytucja z art. $46 \S 1$ k.k. ma charakter kompensacyjny, nie wynika, że sąd jest zobligowany do zasądzenia odsetek, orzekając obowiązek naprawienia szkody - od dnia wyrządzenia szkody. W dalszym ciągu, co wynika z przepisów prawa cywilnego, okoliczność ta powinna zostać oceniona w realiach konkretnej sprawy.

\section{Andrzej Lewna}

Uniwersytet Gdański

andrzej.lewna@ug.edu.pl

ORCID: 0000-0003-0757-4894

https://doi.org/10.26881/gsp.2020.3.14

\section{Glosa}

Komentowane orzeczenie Sądu Apelacyjnego w Warszawie ${ }^{1}$ dotyka niezwykle istotnej z punktu widzenia restytucyjnej funkcji prawa karnego problematyki, odnoszącej się do - wciąż dyskusyjnej w literaturze przedmiotu - kwestii właściwego ujęcia środka kompensacyjnego w postaci obowiązku naprawienia szkody z art. $46 \S 1$ k.k. ${ }^{2}$ oraz możliwości uwzględnienia przez sąd karny w ramach stosowania tego obowiązku zapłaty odsetek od ustalonej sumy pieniężnej należnej pokrzywdzonemu. Rozstrzygnięcie omawianego problemu w aktualnym stanie prawnym, ukształtowanym ustawą z dnia 20 lutego 2015 r., zmieniającą k.k. ${ }^{3}$, pomimo pozornej klaryfikacji dokonanej przez ustawodawcę wspomnianą nowelizacją w odniesieniu do funkcji i charakteru

\footnotetext{
1 Wyrok SA w Warszawie z dnia 5 września 2018 r., II AKa 211/18, Legalis nr 1834736.

2 Ustawa z dnia 6 czerwca 1997 r. - Kodeks karny (tekst jedn.: Dz. U. z 2019 r., poz. 1950 ze zm.; dalej k.k., kodeks karny).

3 Ustawa z dnia 20 lutego 2015 r. o zmianie ustawy - Kodeks karny oraz niektórych innych ustaw (Dz. U. poz. 396; dalej: nowelizacja z 2015 r., nowelizacja k.k., ustawa zmieniająca k.k.).
} 
statutory interest as part of the obligation to repair damages, in the context of views presented in the doctrine on the current normative shape of this compensatory measure and the intentions of recent amendments proposed by the legislator. The author presents the view that the interpretation of art. $46 \S 1$ of the Polish Penal Code presented by the Court of Appeal deserves only partial approval, as in some cases it may lead to an unjustified limitation of compensation of damages and to nullification of the main purpose of the statutory amendment.

Słowa kluczowe: obowiązek naprawienia szkody; kompensacja; środki kompensacyjne; środki karne

Keywords: obligation to repair damage; compensation; compensatory measures; penal measures 